\title{
The earliest Buddhist shrine: excavating the birthplace of the Buddha, Lumbini (Nepal)
}

R.A.E. Coningham ${ }^{1}$, K.P. Acharya ${ }^{2}$, K.M. Strickland ${ }^{3}$, C.E. Davis ${ }^{1}$, M.J. Manuel ${ }^{1}$, I.A. Simpson ${ }^{4}$, K. Gilliland ${ }^{4}$, J. Tremblay ${ }^{1}$, T.C. Kinnaird $^{5} \&$ D.C.W. Sanderson ${ }^{5}$

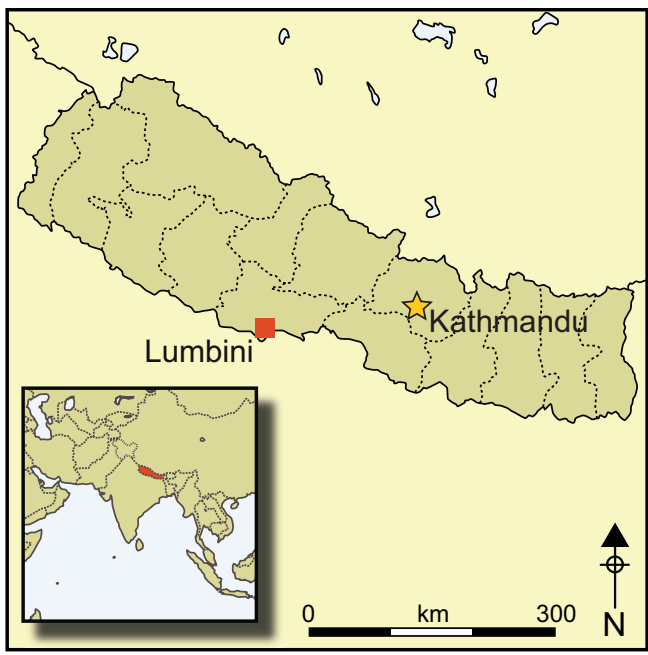

Key locations identified with the lives of important religious founders have often been extensively remodelled in later periods, entraining the destruction of many of the earlier remains. Recent UNESCOsponsored work at the major Buddhist centre of Lumbini in Nepal has sought to overcome these limitations, providing direct archaeological evidence of the nature of an early Buddhist shrine and a secure chronology. The excavations revealed a sequence of early structures preceding the major rebuilding by Asoka during the third century $B C$. The sequence of durable brick architecture supplanting non-durable timber was foreseen by British prehistorian Stuart Piggott when he was stationed in India over 70 years ago. Lumbini provides a rare and valuable insight into the structure and character of the earliest Buddhist shrines.

Keywords: Nepal, Lumbini, first millennium BC, Buddha, Asoka, Mauryan Horizon, shrine, temple

\section{Beyond the 'Mauryan Horizon'}

Although there is much information regarding the Buddha's teachings, most of the evidence used to piece together the character of early Buddhism is textual. Surprisingly perhaps, it is still uncertain when he lived (Coningham 2001, 2011). Dates proposed for his mahaparanirvana, or 'great passing away', at Kusinagara at the age of 80, vary between 2420

\footnotetext{
Department of Archaeology, Durham University, South Road, Durham DH1 3LE, UK

Pashupati Area Development Trust, Kathmandu, Nepal

Orkney College, University of the Highlands and Islands, East Road, Kirkwall, Orkney KW15 1LX, UK

School of Biological and Environmental Sciences, University of Stirling, Stirling FK9 4LA, UK

Scottish Universities Environmental Research Centre, East Kilbride G75 OQF, UK 
and $290 \mathrm{BC}$, although most scholars favour a date around the middle of the first millennium BC (Bechert 1995: 12; Coningham 1998: 122). This diversity reflects conflicting narratives from different Buddhist traditions. These were largely constructed by referring to extant lists of kings and estimating the number of regnal years that elapsed between the mahaparanirvana and the enthroning of Asoka. Most scholars waver between a Nepali and Sri Lankan tradition of $623 \mathrm{BC}$, a long 'southern Buddhist' chronology of 544/3 BC, a long chronology of 480 $\mathrm{BC}$, and short chronologies between 390 and $340 \mathrm{BC}$, although key individuals have begun to favour the shorter chronologies (Bechert 1995: 12-34). The majority of the sites relating to the Buddha's life have been identified, but excavations have failed to expose contexts earlier than the third century BC. Whilst some have suggested that the hope of finding early levels "is almost zero" (Hartel 1995: 142), others have asserted that "only more scientific analyses will provide reliable answers" (Coningham 2005). Part of the problem has been the preoccupation with texts, many of which were compiled centuries later and represent the knowledge of a small elite (Schopen 1997; Coningham 1998, 2001; Trautmann \& Sinopoli 2002). Furthermore, archaeologists have limited themselves to exposing stone and brick Buddhist monuments and have failed to penetrate the 'Mauryan Horizon' (Coningham 1998: 122, 2011: 934). This phrase reflects the spread of brick and stone monuments across South Asia, ascribed to the patronage of Asoka (r. 274-232 BC) (Dittmann 1984). Tradition has assigned Asoka a key role in the propagation of Buddhism (Mitra 1971: 9) and evidence of his patronage is represented by over 50 boulder and pillar inscriptions, some of which recorded his pilgrimages (Falk 2006). The 'Horizon' is particularly strong at the four major Buddhist sites: Lumbini, the Buddha's birthplace; Bodh Gaya, where he became a Buddha or 'enlightened one'; Sarnath, where he first preached; and Kusinagara, where he underwent mahaparanirvana (Mitra 1971: 67; Allchin 1995: 244) (Figure 1). Field investigations have been hindered by the monumentality of Mauryan construction at these locations. In addition, the sites were largely cleared in the nineteenth century before reverting to pilgrimage centres, thus becoming inaccessible for research. However, the recent UNESCO-sponsored mission to Lumbini has facilitated new investigations.

\section{The birthplace of the Buddha and UNESCO}

Lumbini lies within the Nepal Terai, a subtropical chain of forests, marshes and grasslands, now intensively cultivated, between the Indian border and the Siawalik Range of the Himalayas. This gently sloping plateau is bisected by the Ganga's tributaries, creating alluvial fans and meanders. Whilst Sarnath, Kusinagara and Bodh Gaya were rediscovered in the nineteenth century as a result of epigraphical scholarship and the comparison of modern topography with that described by two Chinese pilgrims, Faxian (AD 337-422) and Xuanzang (AD 602-664), Lumbini was discovered by chance when a rubble mound surmounted by a modern shrine to Rupadevi was visited by Dr Fuhrer of the Archaeological Survey of India and General Rana, Governor of Palpa, in 1896 (Mukherji 1901). Their identification was based on topographical similarities with the pilgrims' descriptions and an Asokan inscription recording the name Lumbini (Uesaka 2001: 75) (Figure 2). On investigation, the Gupta-period image of Rupadevi was re-interpreted as Maya Devi (the

(c) Antiquity Publications Ltd. 


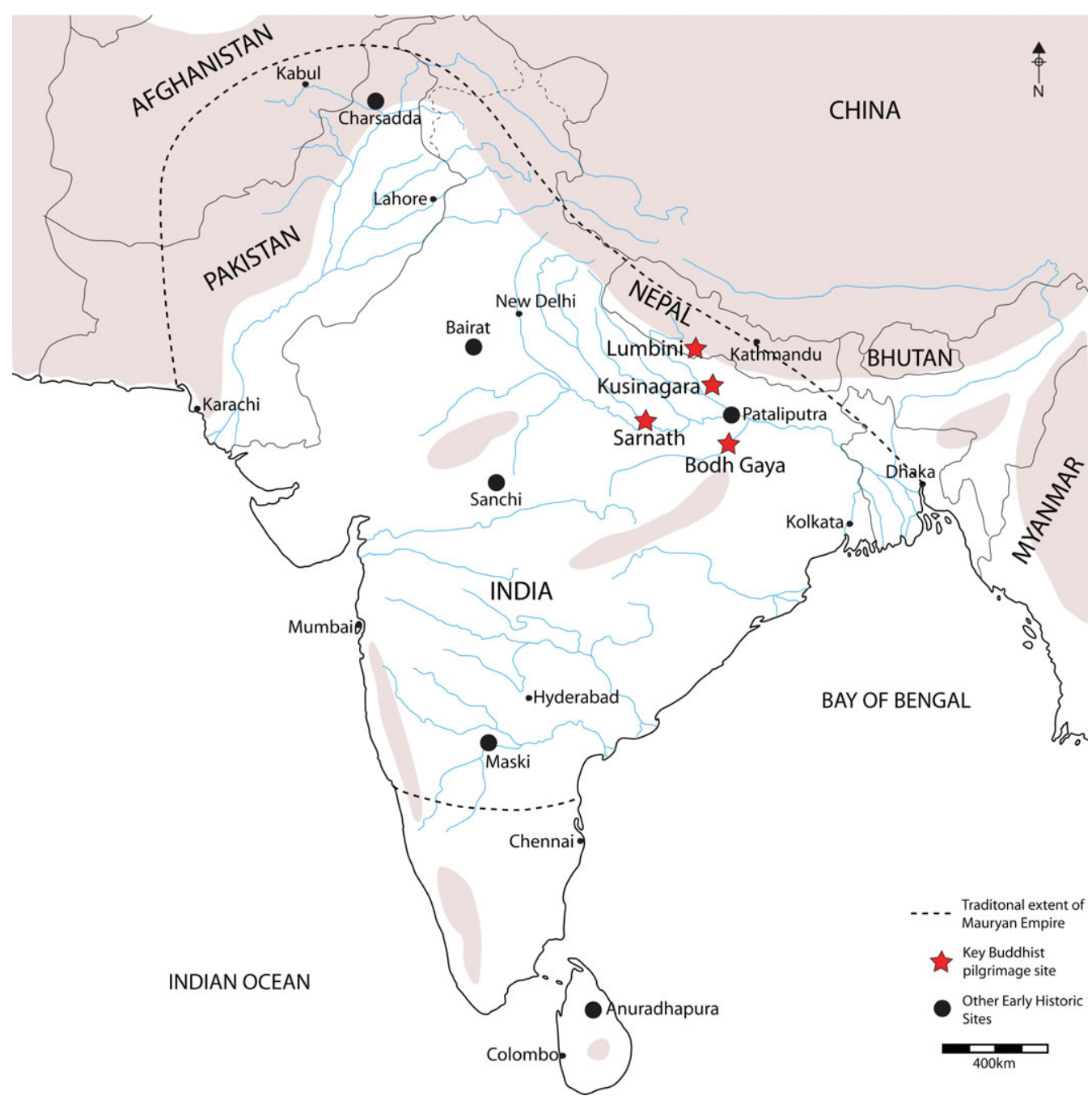

Figure 1. Map of sites mentioned within the text.

Buddha's mother). More than a century of intervention has since led to the clearance of the core monument zone of temples, monasteries and stupas (Coningham et al. 2011) (Figure 3). The latter half of the twentieth century witnessed a major increase in pilgrim numbers, most notably Buddhist (Mitra 1972; Rijal 1979), and the site was inscribed on the UNESCO World Heritage List in 1997.

These monuments were central to the development of a UN Masterplan devised by the Japanese architect Kenzo Tange at the request of Secretary-General U-Thant (Bidari 2002). Before inscription, the Government of Nepal raised concerns about damage to the Maya Devi Temple caused by a tree. The Japanese Buddhist Federation (JBF) was invited to remove it and expose the earliest temple in accordance with Tange's plan. Led by Satoru Uesaka, (C) Antiquity Publications Ltd. 


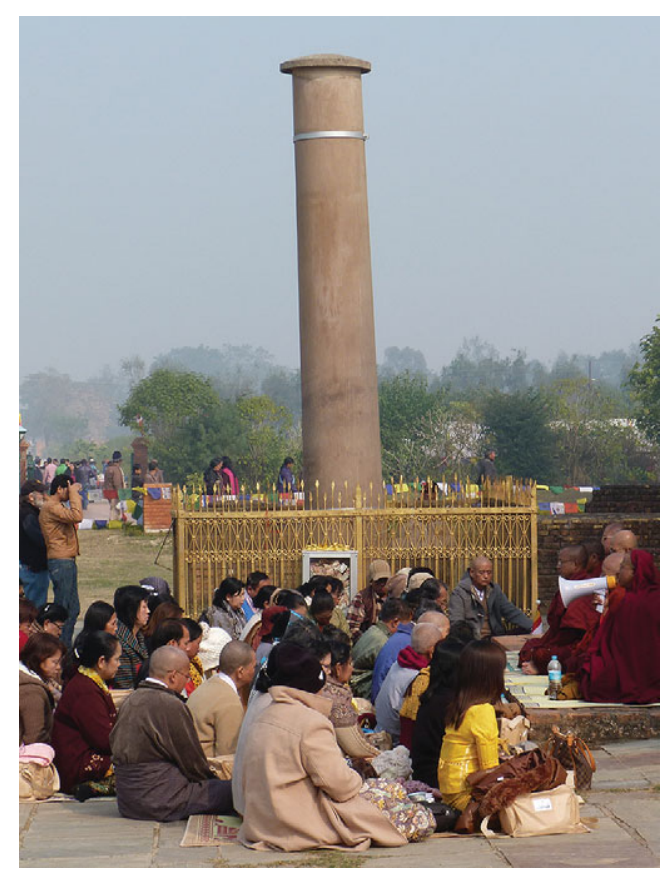

Figure 2. The Asokan pillar at Lumbini. Photo: authors.
Babu Krishna Rijal and Kosh Prasad Acharya, they excavated through a $6 \mathrm{~m}$ sequence of temples, the youngest of which dated to 1939 and the oldest to Asoka's reign. Constructed of bricks measuring 380 $\times 250 \times 70 \mathrm{~mm}$, the latter was unlike other early Buddhist shrines as it was rectangular, measuring $26 \mathrm{~m}$ north to south and $21 \mathrm{~m}$ east to west. Internal walls created 15 subdivisions, which were interpreted as 'chambers' (Uesaka 2001: 38) (Figure 4), reflecting Uesaka's belief that the walls were erected and the resultant 'chambers' filled to provide a raised platform (Uesaka 2001: 55). As such, the JBF removed most of the 'filling' to expose the foundations. During these excavations, they encountered a conglomerate block that they termed the 'Marker Stone', proposing that it signified where Buddha was born (Uesaka 2001) (Figure 5).

It was recognised that the Asokan brickwork would deteriorate unless protected, and UNESCO commissioned a reactive monitoring mission to evaluate the design concepts for a new shelter. These designs were deemed unsuitable owing to their intrusive foundations and the damage they might do to earlier cultural surfaces below the Asokan temple (Coningham \& Milou 2001). This latter concern was fuelled by the re-examination of the limited section drawings from the JBF project and by Acharya's hypothesis that the deposits within the 'chambers' were not fill but rather old land surfaces isolated by the Asokan foundation trenches. Despite concerns voiced at an international technical meeting that a closed shelter would lead to the creation of micro-environments that would adversely affect the monument, construction work commenced in 2002. As anticipated, increased humidity within the shelter accelerated the degradation of the brickwork, exacerbated by increasing pilgrim numbers. Furthermore, the Asian Development Bank reacted to predictions of a rise in visitor numbers from 500000 a year to 2 million by 2020 with the investment of US\$ 87.5 million to upgrade Lumbini's roads and airport. UNESCO responded to the projected impact of these developments by launching a three-year intervention entitled Strengthening the Conservation and Management of Lumbini; the Birthplace of Lord Buddha, World Heritage Property. This was supported by the Japanese Funds-in-Trust for UNESCO and led by Professor Nishimura of Tokyo University. Core to this project was the need to evaluate the presence of early archaeological sequences within the Temple to protect them from future development. A team, directed by Robin Coningham and Kosh Prasad Acharya, was approved to excavate under the Asokan temple foundations (Coningham \& Acharya 2011, 2012) (Figure 6). 


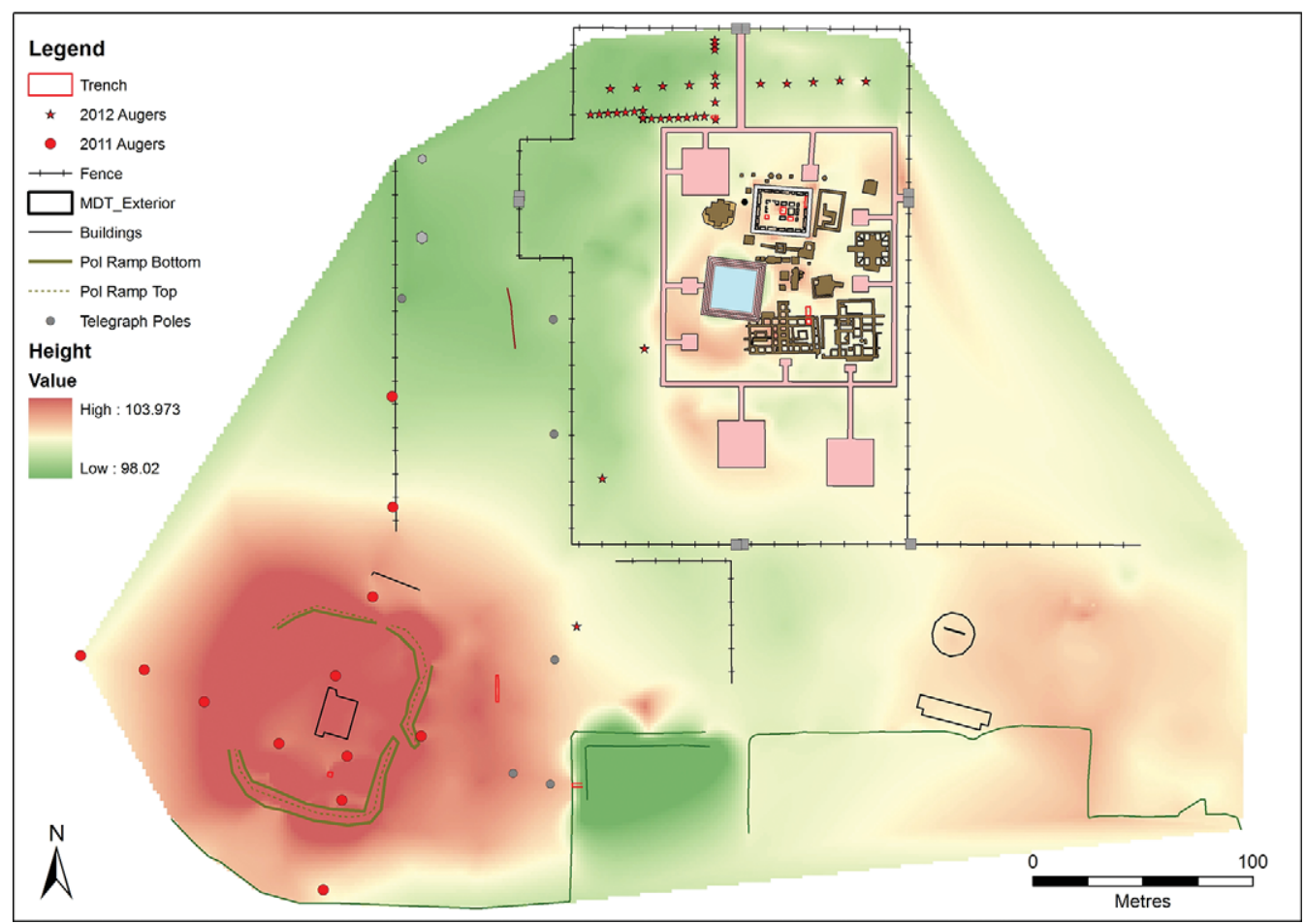

Figure 3. Plan of Lumbini, with the Sacred Garden complex to the north, and village mound to the south-west.

\section{Excavating within the Maya Devi Temple, 2011 and 2012}

The cleaning of the sections left by the JBF in trenches C5, C7, C13 and ENE exposed in situ cultural horizons beneath the Asokan walls, confirming Acharyas hypothesis that earlier activity pre-dated the 'Mauryan Horizon'. Indeed, OSL measurements from early land surfaces, contexts 508 and 509, within Trench C5 yielded dates of 545 $\pm 235 \mathrm{BC}$, and $990 \pm 290 \mathrm{BC}$ respectively. In addition, a radiocarbon date of 788-522 BC was obtained from context 561, another early cultural layer in Trench C5b (see Tables 1 \& 2). Furthermore, ceramics recovered from the earliest cultural deposits included Cord Impressed Ware, which is found within regional Iron Age ceramic assemblages (Singh 1994: 107; Verardi 2007: 245-49). During the excavations, we were also able to distinguish the presence of at least two construction phases within the Asokan temple and roof tiles and lime plaster in contexts associated with its levelling. Our activities, however, were mainly focused in the centre of the temple in Trench C5. This represented the largest area of unexcavated material because the JBF had halted their work when they encountered "two rows of bricks" (Uesaka 2001: 51). When the surface of C5 was cleaned in 2012, we exposed an irregular brick pavement defined by an east-west kerb (Figure 7). This kerb was found to comprise large bricks measuring a maximum $520 \times 380 \times 75 \mathrm{~mm}$, weighing $19 \mathrm{~kg}$ each, and marked with finger grooves on one surface. Once the brick pavement had been planned and removed, two earlier phases were identified and it was clear that the kerb had defined the edge of three successive (C) Antiquity Publications Ltd. 


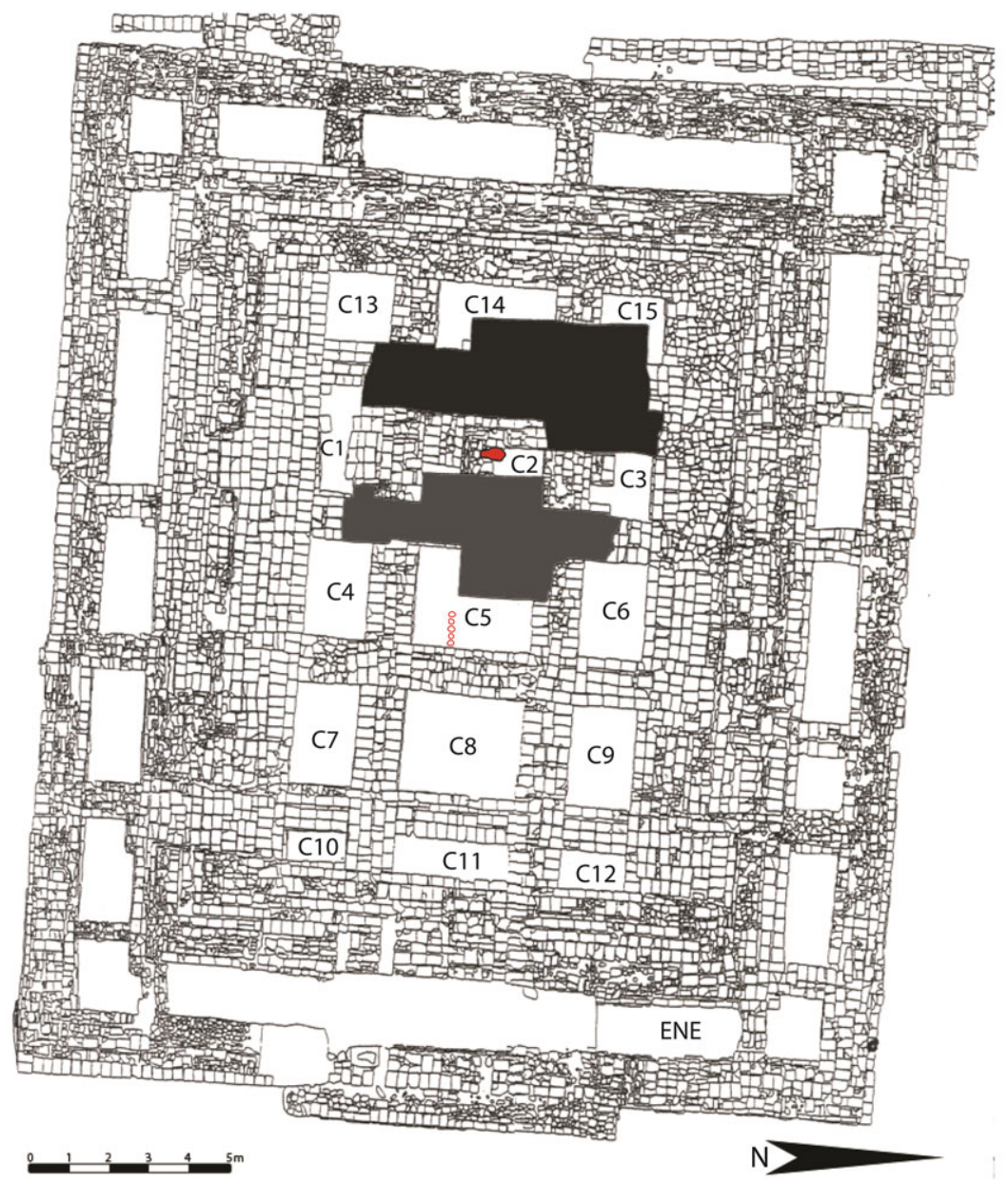

Figure 4. Plan of the later phases of the Maya Devi Temple, showing the location of the 'chambers' excavated by the JBF team. The Marker Stone within C2, and the series of postholes in C5b are highlighted in red. The modern temple shelter is constructed above this earlier temple. Redrawn from the JBF plan.

pavements. Not only did these pavements run underneath the Asokan walls, the kerb itself was incorporated into the foundations of the Asokan temple, confirming that it was part of a pre-Asokan brick structure. As the lowermost pavement and kerb were removed, a series of six postholes following the same east-west alignment were exposed in the deposit below (Figure 8). This was highly significant: the kerb had replaced a line of wooden posts that had previously defined this space. Not only was there evidence of permanent constructions older than the Asokan temple but the presence of non-durable architecture had also been identified. Radiocarbon samples from two contemporary posthole fills (contexts 553 and 557) provided dates of 799-546 BC and 801-548 BC (Table 1), suggesting an extremely early delineation of sacred space within this locality, and pushing activity at Lumbini far before the reign of Asoka.

(C) Antiquity Publications Ltd. 


\section{Discussion: the earliest Buddhist shrine?}

Such a sequence had already been predicted over 70 years ago by the European prehistorian Stuart Piggott. Stationed in India between 1941 and 1945, Piggott produced a series of

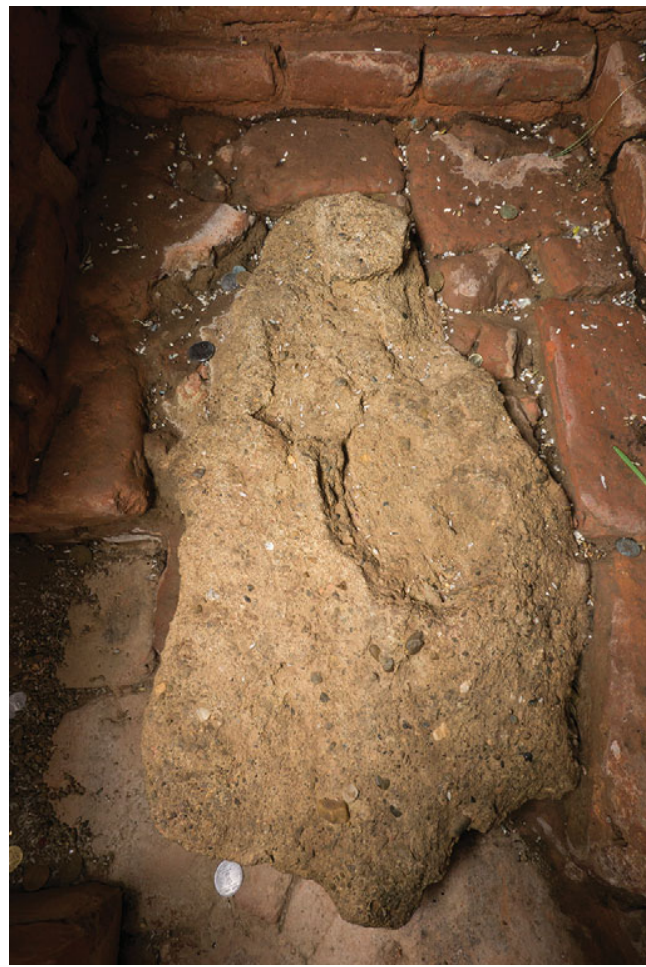

Figure 5. The Marker Stone. Photo: Ira Block. papers on the archaeology of the Subcontinent (Piggott 1944, 1945, 1947, 1950). In Antiquity in 1943, he reviewed Sahni's excavations at Bairat in Rajasthan in a paper called 'The earliest Buddhist shrines' (Piggott 1943). Already known for its Asokan inscriptions, Sahni exposed a circular Buddhist shrine enclosing a brick stupa. Constructed of brick with timber pillars, wall plaster and clay roof tiles, Sahni noted that its plan was a "new type" and attributed it to Asokan patronage (1937: 39). Piggott reinterpreted Sahni's phasing, suggesting that it was the result of multiple embellishments, and that its earliest form comprised a circular brick shrine with an inner colonnade of octagonal timber pillars, subsequently encased within a rectangular brick shrine (Figure 9). He also noted the presence of the "most remarkable balustrades, railings, and finally monumental gateways, made of stone but accurately copying a carpentry technique" at a number of Buddhist sites (Piggott 1943: 7). Drawing analogies with recently discovered wooden precursors of Stonehenge and the identification of fencing delimiting Bronze Age barrows (Piggott 1943: 9), he suggested that these monumental Buddhist stone railings referenced earlier wooden fences (Figure 10). Piggott further postulated that the earliest Buddhist shrines were constructed of perishable materials and stated his hope that "eventually the timber prototypes. . will be identified and excavated" (Piggott 1943: 7).

Seventy years later, our research at Lumbini has endorsed Piggott's assertion that there "is very strong presumptive evidence therefore for the existence in pre-Mauryan, and probably in Mauryan India too, of ritual wooden fences delimiting sacred areas" (1943: 7). Indeed, our excavations have demonstrated that the earliest construction at Lumbini appears to have comprised a timber fence or railing marking a cardinal direction. Significantly, this division of space was imposed upon undifferentiated layers of charcoal, clay and smashed ceramic vessels. This alignment was subsequently enshrined with the more durable construction of a kerb and pavement, continuing to define movement and space until the Asokan redevelopment. This latter phase drastically altered the Temple layout and focus of veneration with the installation of the 'Marker Stone'. It is worth reflecting that Trench C5 was located at

(C) Antiquity Publications Ltd. 


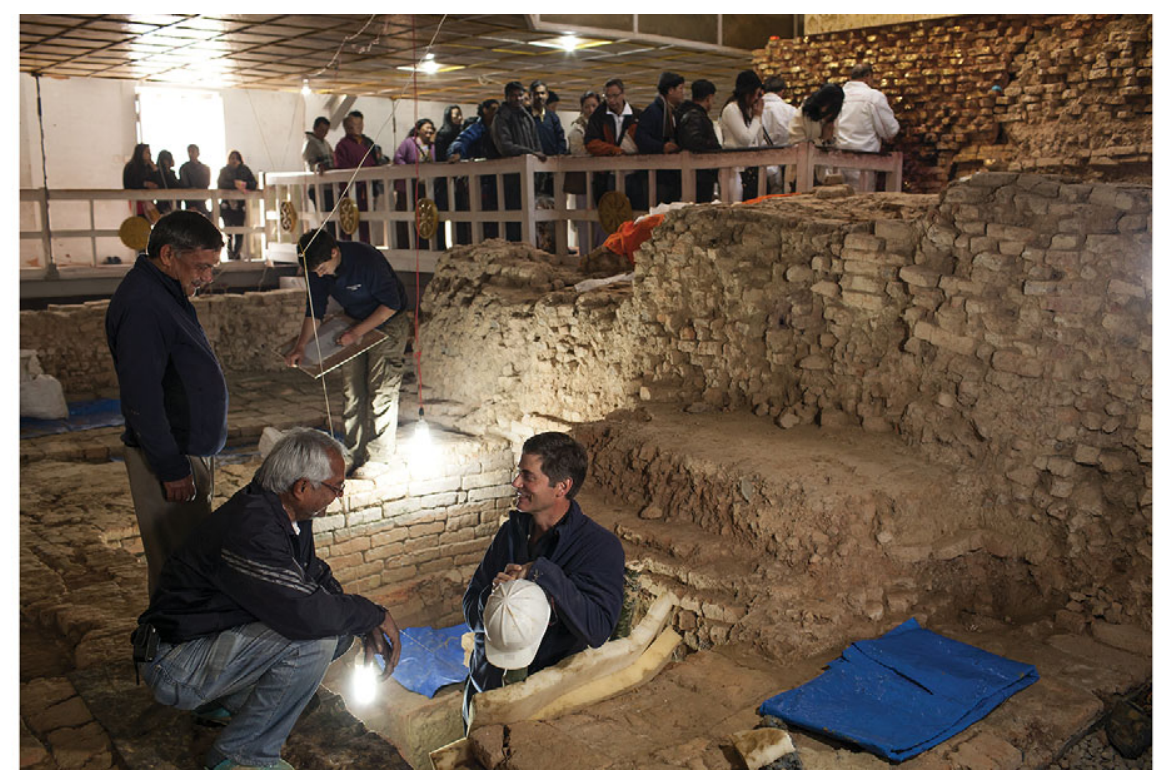

Figure 6. View of the excavations in C5 within the Maya Devi Temple. The Marker Stone is situated below the pilgrims. Photo: Ira Block.

the centre of the Asokan temple and to the east of the 'Marker Stone' (Uesaka 2001: 55). Therefore, the kerb and timber alignments contributed to the cardinal definition of a central space within what was the earliest phase of development. The hypothesis that these mud surfaces and brick pavements were part of walkways or platforms gains further support from the absence of any great accumulation of cultural material, suggesting regular cleaning.

This new work inside the Maya Devi Temple presents a unique sequence of ritual development at the centre of one of the most important Buddhist pilgrimage sites. The Asokan temple comprised a cardinally orientated platform defined by two phases of foundations with no evidence of a brick superstructure. The JBF suggested that the Asokan brick superstructure had been levelled later, but we suggest that lines of postholes cut into the surface of the southern and eastern walls of the temple may have supported a timber superstructure. Roof tiles were recorded in Trench C13 and deposit C8 in the JBF report (Uesaka 2001: 108), indicating that part of the temple was roofed. No tiles were encountered within C5, suggesting that the central area may have been open. We also know that the Asokan monument incorporated an earlier phase of brick construction, which comprised a cardinally orientated double kerb with a pavement or platform to its south. The bricks themselves were distinctive and more of them were identified at the same level in C13 at the south-west and in C9 and C12 (Uesaka 2001: 38-53). This suggests that the retaining kerb defining the centre of the shrine was surrounded by a pavement of broken and complete bricks of the same type on the southern, south-western and north-western sides. It is significant that no structures were identified within the centre of C5 (Figure 11).

What was the character of the apparent void at the centre of the Asokan and pre-Asokan temples? Whilst the area was visibly clear of construction materials and the deposits were clean apart from small ceramic sherds and charcoal flecks, there was some disturbance by

(C) Antiquity Publications Ltd. 
Table 1. Radiocarbon determinations from Trench C5b within the Maya Devi Temple.

\begin{tabular}{|c|c|c|c|c|c|c|c|}
\hline Lab code & Sample & Site & Trench & Context & ${ }^{14} \mathrm{C}$ age $\mathrm{BP}$ & $\begin{array}{l}\text { Calibrated } \\
68.2 \%(1 \sigma)\end{array}$ & $\begin{array}{l}\text { Calibrated } \\
95.4 \%(2 \sigma)\end{array}$ \\
\hline $\begin{array}{l}\text { SUERC- } \\
42856 \\
\text { (GU28693) }\end{array}$ & $\mathrm{X} 70$ & MDT & $\mathrm{C} 5 \mathrm{~b}$ & $\begin{array}{l}553 \text { (posthole } \\
\text { fill) }\end{array}$ & $2540 \pm 30$ & $\begin{array}{c}793-751 \mathrm{BC} \\
(34.7 \%) \\
687-667 \mathrm{BC} \\
(15.4 \%) \\
637-622 \mathrm{BC} \\
(7.1 \%) \\
615-594 \mathrm{BC} \\
(11.0 \%)\end{array}$ & $\begin{array}{c}799-734 \mathrm{BC} \\
(39.4 \%) \\
691-662 \mathrm{BC} \\
(17.7 \%) \\
650-546 \mathrm{BC} \\
(38.2 \%)\end{array}$ \\
\hline (GU28694) & X71 & MDT & $\mathrm{C} 5 \mathrm{~b}$ & 555 & Failed & & \\
\hline $\begin{array}{l}\text { SUERC- } \\
42857 \\
\text { (GU28695) }\end{array}$ & $\mathrm{X} 72$ & MDT & $\mathrm{C} 5 \mathrm{~b}$ & $\begin{array}{l}557 \text { (posthole } \\
\text { fill) }\end{array}$ & $2548 \pm 30$ & $\begin{array}{c}796-752 \mathrm{BC} \\
(41.6 \%) \\
686-667 \mathrm{BC} \\
(15.0 \%) \\
633-625 \mathrm{BC} \\
(3.4 \%) \\
613-596 \mathrm{BC} \\
(8.2 \%)\end{array}$ & $\begin{array}{c}801-741 \mathrm{BC} \\
(46.4 \%) \\
690-663 \mathrm{BC} \\
(17.4 \%) \\
648-548 \mathrm{BC} \\
(31.6 \%)\end{array}$ \\
\hline $\begin{array}{l}\text { SUERC- } \\
42861 \\
\text { (GU28696) }\end{array}$ & X85 & MDT & $\mathrm{C} 5 \mathrm{~b}$ & $\begin{array}{l}561 \text { (early } \\
\text { cultural layer) }\end{array}$ & $2505 \pm 30$ & $\begin{array}{c}766-745 \mathrm{BC} \\
(10.5 \%) \\
688-664 \mathrm{BC} \\
(10.4 \%) \\
647-551 \mathrm{BC} \\
(47.2 \%)\end{array}$ & $\begin{array}{c}788-522 \mathrm{BC} \\
(95.4 \%)\end{array}$ \\
\hline $\begin{array}{l}\text { SUERC- } \\
42862 \\
\text { (GU28697) }\end{array}$ & $\mathrm{X} 90$ & MDT & $\mathrm{C} 5 \mathrm{~b}$ & $\begin{array}{l}562 \text { (natural } \\
\text { soil) }\end{array}$ & $3315 \pm 30$ & $\begin{array}{c}1627-1601 \mathrm{BC} \\
(20.4 \%) \\
1593-1532 \mathrm{BC} \\
(47.8 \%)\end{array}$ & $\begin{array}{c}1681-1521 \mathrm{BC} \\
(95.4 \%)\end{array}$ \\
\hline
\end{tabular}

Note: the sampling was undertaken in January 2012, and submitted for dating at the AMS Facility at the Scottish Universities Environmental Research Centre. The ${ }^{14} \mathrm{C}$ age is quoted in conventional years BP (before $1950 \mathrm{AD}$ ). The calibrated age ranges are determined from the University of Oxford Radiocarbon Accelerator Unit calibration program (OxCal3) (Bronk Ramsey 1995, 2001).

large root channels visible within the east-facing section (contexts $513 \& 505$ ). Furthermore, thin-section micromorphology of the stratigraphy has confirmed field observations and has allowed us to distinguish three main phases of site formation. The earliest phase dated from the end of the second millennium BC and was characterised as a cultivated floodplain horizon, associated with micromorphological indicators of persistently wet alluvial soil amendment, surface vegetation burning and cultivation activity (context 510, see Figure 11). Cultural evidence included rare bone fragments together with more frequent wood ash and charcoal. Cultivation disturbance was indicated by the orientation and compaction of the alluvial clay in cultivation pans and by the mixing of contrasting alluvial sediments, while phytoliths indicated vegetation-covered land surfaces. This phase provides evidence of prestructural cultivation in the vicinity of the site, presumably linked to the contemporary settlement mound under the modern police station a few hundred metres to the (C) Antiquity Publications Ltd. 
Table 2. OSL determinations from Trench C5 within the Maya Devi Temple.

\begin{tabular}{lclcccc}
\hline SUTL no. & $\begin{array}{c}\text { Field } \\
\text { no. }\end{array}$ & Location & $\begin{array}{c}\text { Dose rate } \\
(\mathrm{mGy} a-1)\end{array}$ & $\begin{array}{c}\text { Stored } \\
\text { dose }(\mathrm{Gy})\end{array}$ & $\begin{array}{c}\text { Age } \\
(\mathbf{k a})\end{array}$ & $\begin{array}{c}\text { Calendar } \\
\text { years BC }\end{array}$ \\
\hline SUTL-2368 & OSL1 & $\begin{array}{c}\text { Tr. C5; Cont. 510 } \\
\text { (natural clay deposit) }\end{array}$ & $3.99 \pm 0.37$ & $15.27 \pm 0.25$ & $3.5 \pm 0.3$ & $1520 \pm 340$ \\
SUTL-2369 & OSL2 & $\begin{array}{c}\text { Tr. C5; Cont. 509 (early } \\
\text { land surface) }\end{array}$ & $3.40 \pm 0.33$ & $10.19 \pm 0.12$ & $3.0 \pm 0.3$ & $990 \pm 290$ \\
SUTL-2370 & OSL3 & $\begin{array}{c}\text { Tr. C5; Cont. 508 (early } \\
\text { land surface) }\end{array}$ & $3.31 \pm 0.30$ & $8.47 \pm 0.09$ & $2.6 \pm 0.2$ & $545 \pm 235$ \\
\hline
\end{tabular}

Note: the sampling, together with field dose rate measurements, was undertaken in January 2011 and January 2012, and submitted for dating at the luminescence laboratories of the Scottish Universities Environmental Research Centre. All samples were subjected to laboratory preparation of sand-sized quartz. The purity of the quartz concentrate was checked using scanning electron microscopy. Dose rates for the bulk sediment were evaluated using analyses of the uranium, thorium and potassium concentrations obtained by high resolution gamma spectrometry coupled with beta dose rate measurement using thick source beta counting. Equivalent doses were determined by OSL from 16 aliquots of quartz per sample using the quartz single-aliquot-regenerative (SAR) procedure. The material exhibited good OSL sensitivity and produced acceptable SAR internal quality control performance. Dose distributions were analysed using radial plotting methods and ranked scatter plots.

south-west. This early agricultural, or cultivated, landscape was rapidly covered during the second phase by culturally-deposited alluvial sediments (see Table 2). The sharp contrasts between these two phases indicate the artificial construction of a mound above the wet floodplain in the sixth century BC. The presence of an open area at the centre of the early temple structure also is indicated by the presence of clay accumulation (textural pedofeatures) in a number of root channels and on coarse (silt-sized) mineral grains, together with the accumulation of organic coatings in pore spaces. Moreover, this open centre was associated with evidence of substantial root features (context 513), where iron deposition preserved the structure of organic fragments, through to micron-scale root channels infilled with recrystallised mineral material. This phase was also associated with increased frequencies of fine organic materials but with no increase in phytoliths, leading to the interpretation that additional organic material was culturally deposited within the centre but not cultivated in its vicinity. The third phase of formation was associated with evidence of construction activity superimposed around the open area and was evidenced as large angular clay domains with fine charcoal materials evident throughout this material. We have interpreted these as associated with wattle and daub structures, quite distinct from the area of sediment disturbance and brickwork immediately above, which later sealed the central void.

When faced with similar voids at the centre of later shrines in Sri Lanka, Senake Bandaranayake (1974: 188) suggested that they represented bodhigaras or shrines around a living tree. The bodhigara is a common feature of contemporary Sri Lankan Buddhist temples (Bandaranayake 1974: 161) and was recorded by early European visitors to South Asia (Nugteren 2005: 234-35). The seventeenth-century British merchant Robert Knox noted the veneration of Bodhi trees and described the care paid to them, which is particularly illuminating in relation to the lack of cultural deposits found on the pavements at Lumbini (Knox 1681: 35): "There are many of these trees, which they... have more care of than of any other. They pave round about them like a key; sweep often under them to keep

(C) Antiquity Publications Ltd. 

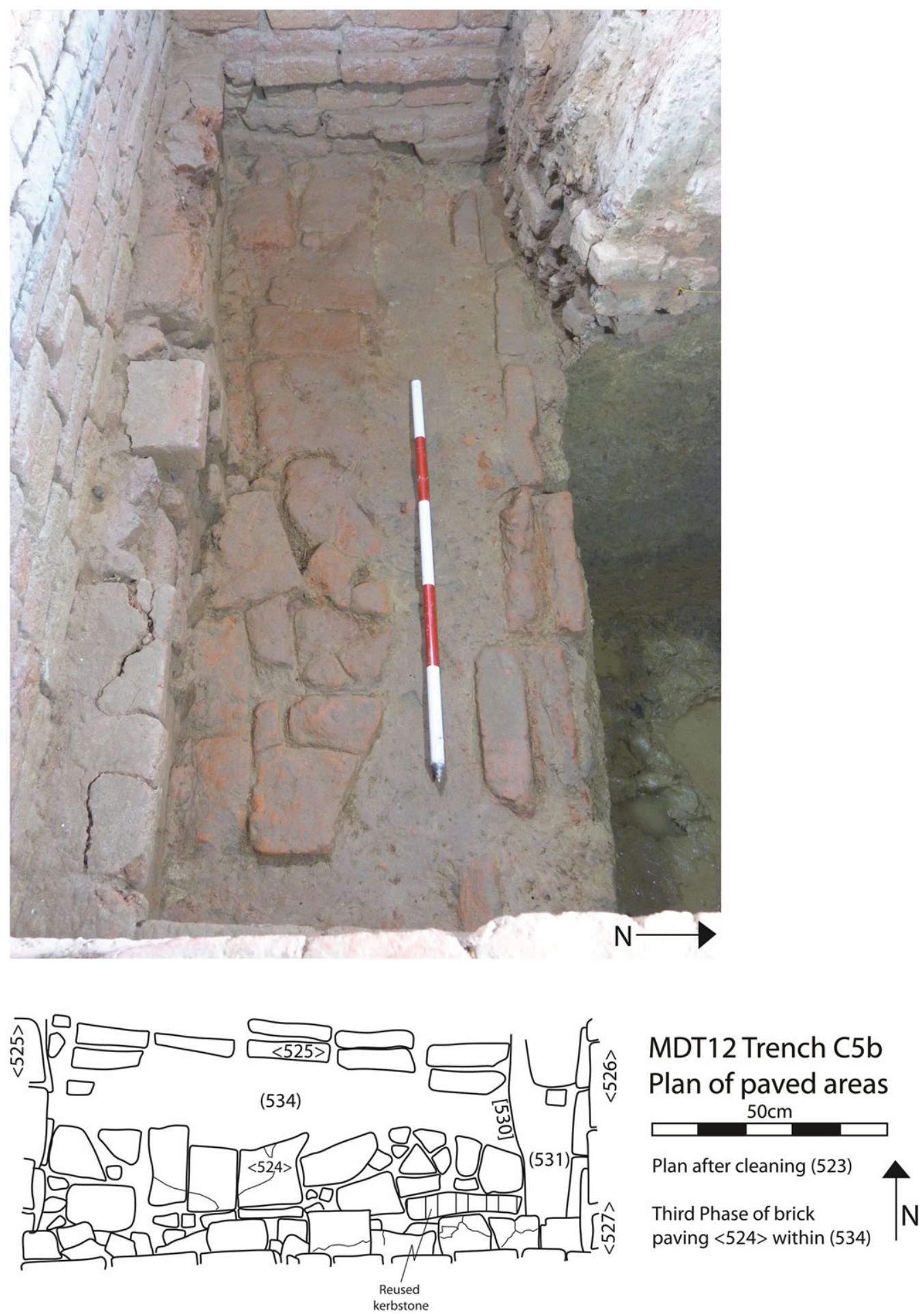

Figure 7. Image and plan of kerb and pavement with thick bands of clay below the bricks visible on the right-hand side of the image.

(C) Antiquity Publications Ltd. 

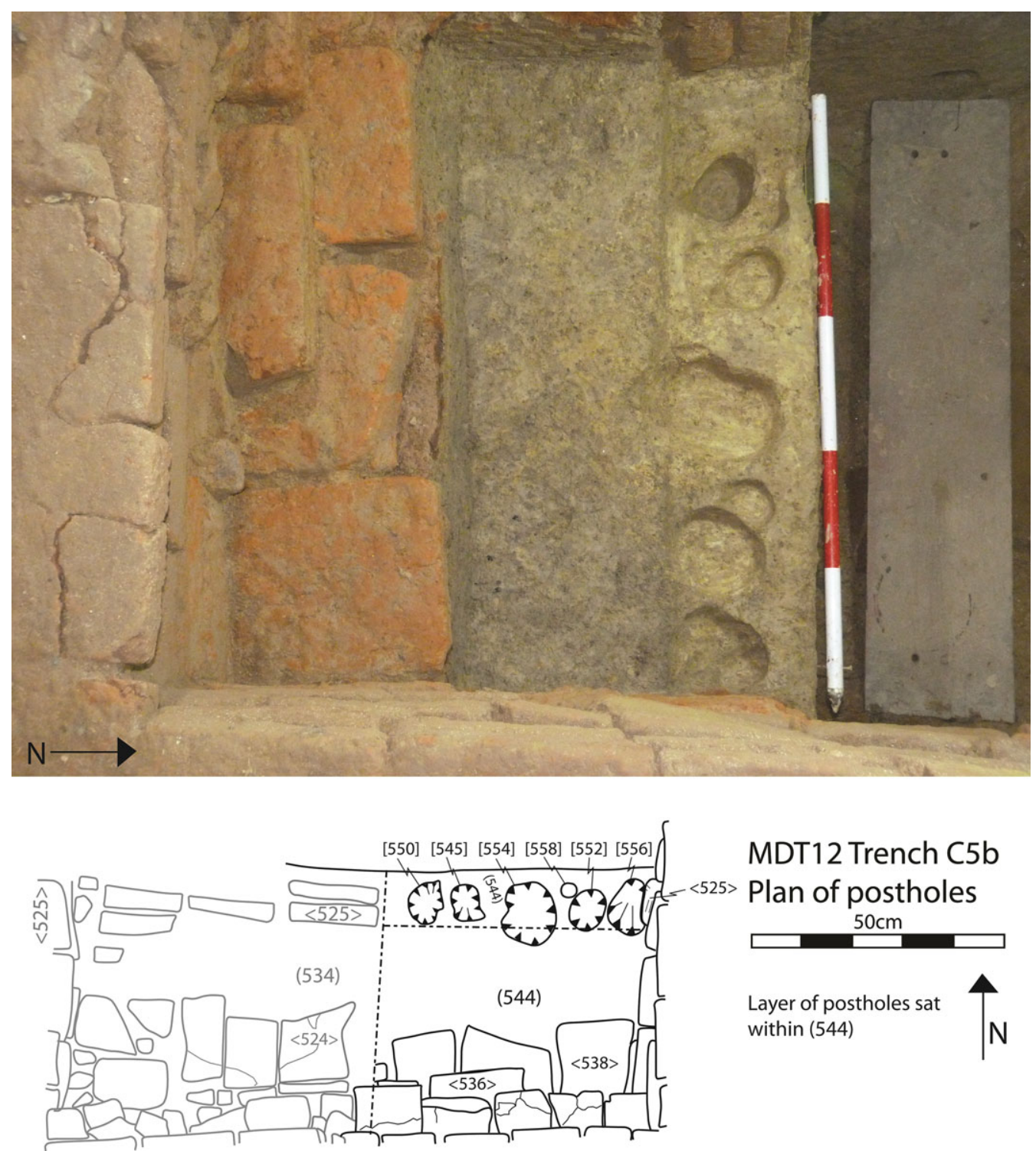

MDT12 Trench C5b

Plan of postholes

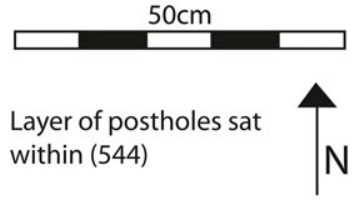

Figure 8. Image and plan of posthole line cut into context 544.

them clean". The presence of a bodhigara at one of the earliest Buddhist shrines would be unsurprising as there are sculptural depictions of them at Bharhut, Sanchi, Bodh Gaya, Mathura, Amravati (Coomaraswamy 1930) and Pauni (Deo \& Joshi 1972) (Figure 12). Indeed, the first-century-BC medallions on the railing at Bharhut depicted garlanded and decorated trees, some of which were furnished with altars and surrounded by tiled roofs (Cunningham 1879: pl. XXIX-XXXI). At the contemporary site of Sanchi, the gateway of Stupa 1 depicted a roof with a tree protruding through (Dehejia 1997: 126). Whilst its popularity was replaced by the advent of the Buddha image, the bodhighara remained a key

(C) Antiquity Publications Ltd. 


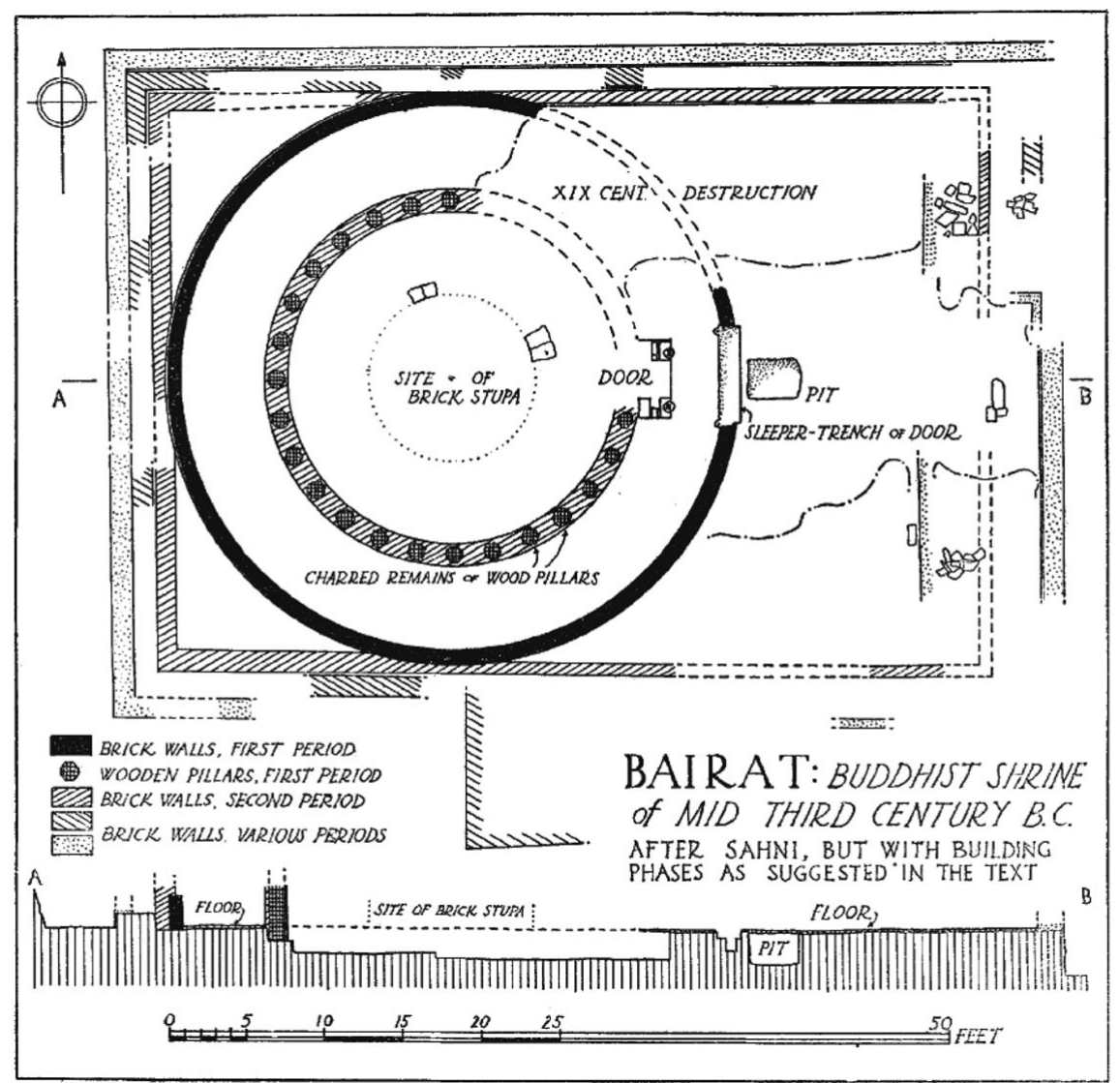

Figure 9. Piggott's reworked plan of Bairat, after Sahni's plan (after Piggott 1943: 3, fig. 1).

monument and trees within railings are also depicted on ancient coins (Cunningham 1891; Pieper 1991; Bopearachchi \& Pieper 1998; Bopearachchi 2006) (Figure 13).

Finally, it should be noted that Early Historic traditions record trees at Bodh Gaya and at Anuradhapura in Sri Lanka. The latter is described by the Pali Chronicle, the Mahavamsa (xviii-xix; Geiger 1929), as having been taken as a cutting from Bodh Gaya and given to the Sri Lankan king by Asoka. It was venerated through the subsequent millennia. Even after the city of Anuradhapura was abandoned, monks remained at the Maha Bodhi tree to care for it, burning fires around the shrine to keep wild elephants away (Marcus Fernando 1965: 7) (Figure 14). Despite the importance of the Bodhi tree in Buddhism (Bandaranayake 1974: 161) and evidence of their presence during the Early Historic period, bodhigaras have received little archaeological attention (Coningham 2001: 76). Perhaps this is even more surprising when one considers that tree shrines are generally held to have been a well-established and ancient form of ritual focus in South Asia, some scholars suggesting an antiquity stretching back to Neolithic times (Irwin 1973: 715). Although now typically associated with Buddhism in the form of bodhigaras, tree shrines also formed a significant (C) Antiquity Publications Ltd. 


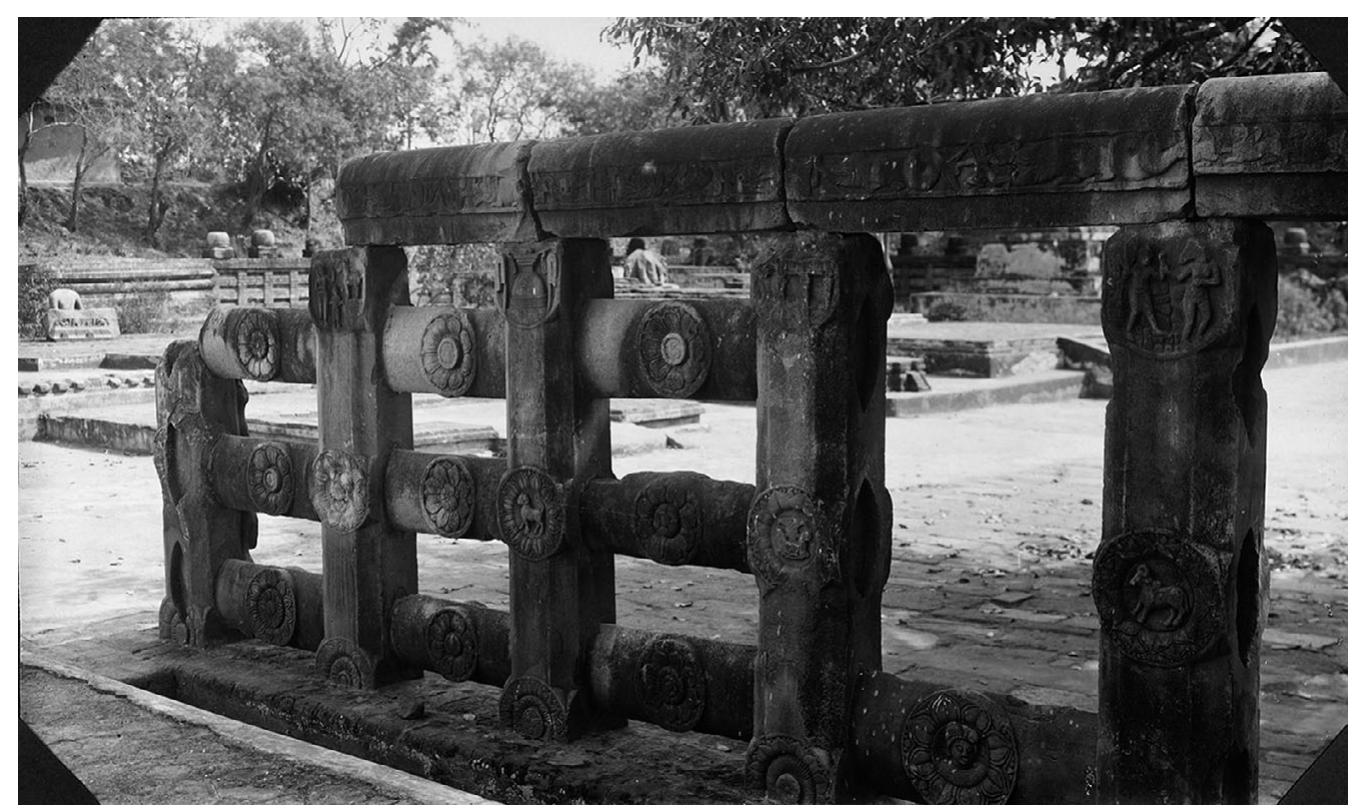

Figure 10. Stone railing at Bodh Gaya, Bihar, India, constructed in a manner similar to wooden railings. From the Marshall photograph collection, held at the Oriental Museum, Durham University (Volume 41, \# 3234).

element of the wider South Asian cosmology, serving as both a social and cosmological central point or axis mundi within communities (Nugteren 2005: 48).

Indeed, the origins of the South Asian tree shrine are embedded within cosmological motifs and concepts. For example, it has been argued that the archetypal image of the separation and unity of the universe was the tree, with its roots reaching into the subterranean waters and the branches into the heavens (Irwin 1982: 345). Thus the tree was at the world's axis and was sometimes represented as a wooden pillar. Whilst pushing up the sky, the tree or pillar simultaneously pegged the primordial mound to the cosmic ocean (Irwin 1983: 256). Such symbolism is thought to have extended to later architecture and the axis represented by a pillar was incorporated into Buddhist stupa design, where it was known as a yupa-yasti (Harvey 1984: 77). Irwin suggested that early stupas had axis sockets, some containing perishable remains, such as the waterlogged wooden axis post found at Lauriya-Nandagarh (Irwin 1979). A number of Sri Lankan stupas had stone axis poles, although none remain in situ (Paranavitana 1946: 35). Irwin further argued that the design of Asokan pillars, with the shaft rising out of the ground without any visible base or plinth, was designed to evoke trees and, by extension, the symbolism of the axis mundi rising from the cosmic ocean below the earth (Irwin 1976: 738).

Therefore, not only are the investigations at Lumbini providing the first scientifically dated pre-Asokan architecture at a Buddhist shrine but potentially the first at a tree shrine. Although much of the fill was removed by the JBF, micromorphological analysis has confirmed substantial root features within an open environment at the centre of the temple. Fine organic materials were brought here from outside, perhaps to raise, deepen or improve the soil. Consequently, the posthole and brick kerb alignments in Trench C5 may

(C) Antiquity Publications Ltd. 

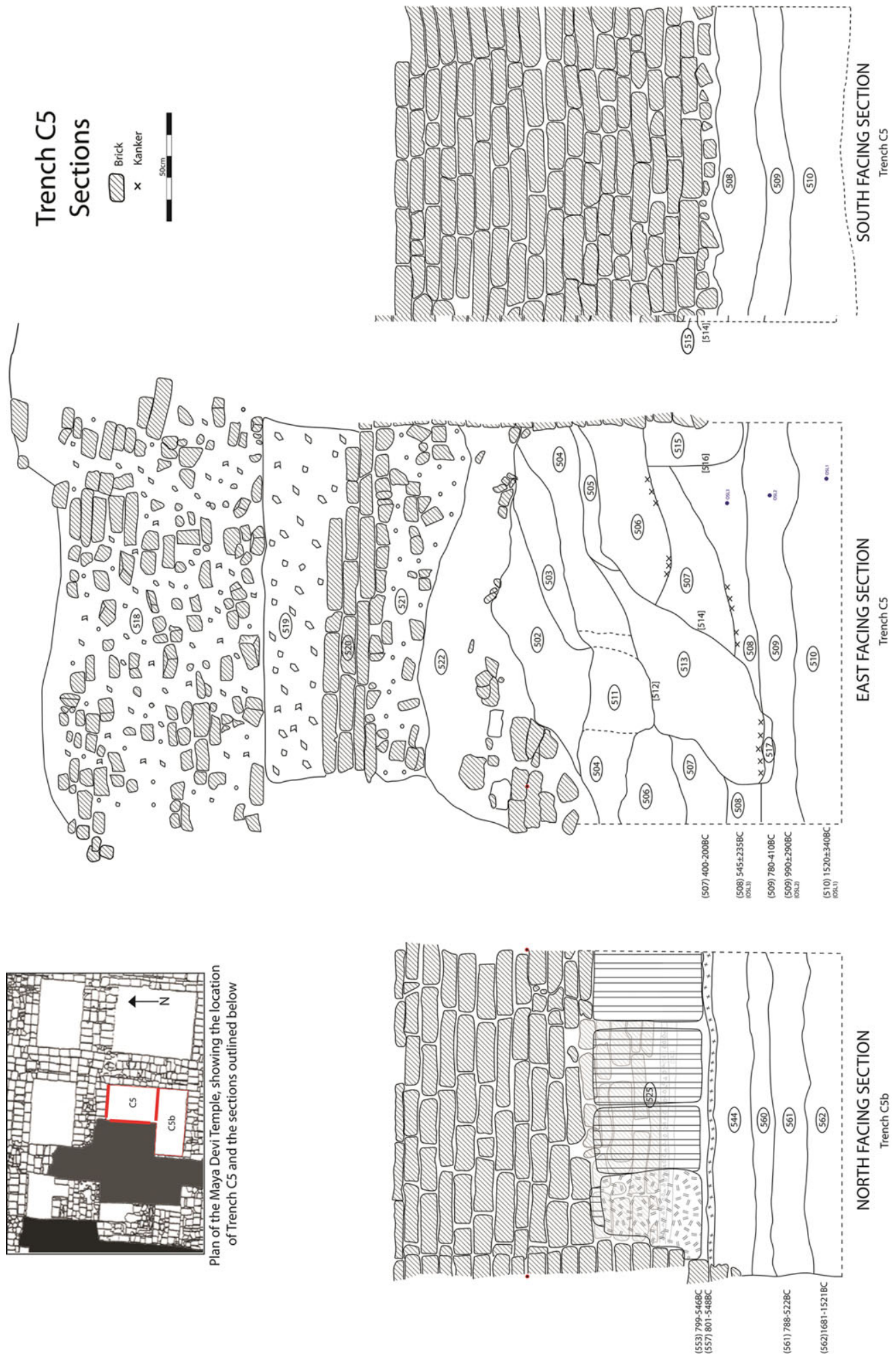

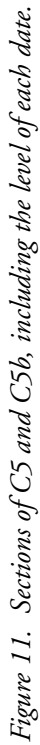

(C) Antiquity Publications Ltd. 


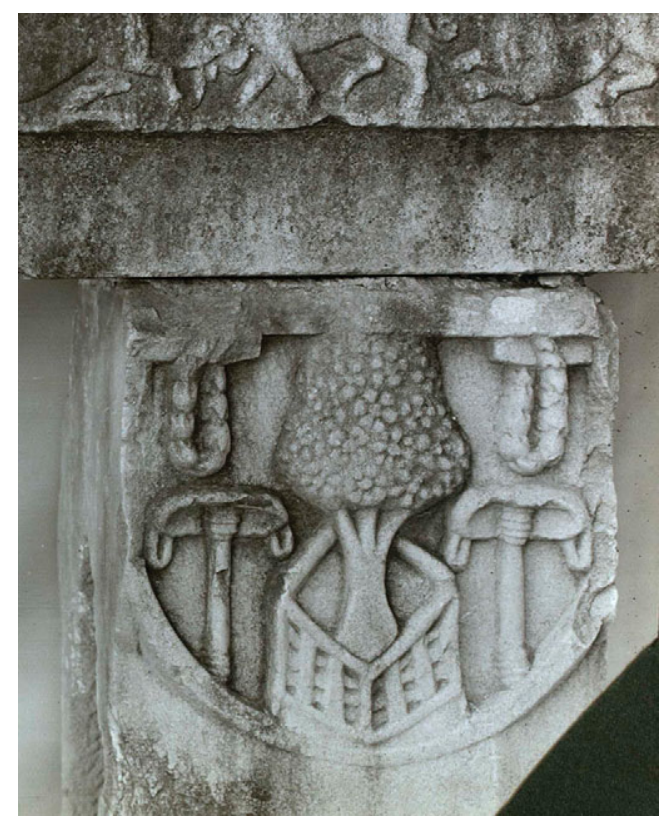

Figure 12. Bas-relief of Bodhi Tree at Bodh Gaya, Bihar, India. From the Marshall photograph collection, held at the Oriental Museum, Durham University (Volume 41, \# 3241). have enclosed a central tree. A tree is described at Lumbini in the itinerary of Xuanzang (Falk 2006). This is not to suggest, of course, that the same tree had grown here for two and a half millennia but we note the examples of trees at Anuradhapura and Bodh Gaya that were maintained, replenished and replaced in order to maintain a focus for veneration. Indeed, Alexander Cunningham suggested that the popularity of the tree was due to "its capacity of being multiplied, so that it was possible for all great kings and great cities to become possessors of scions of the holy tree" (Cunningham 1879: 107). If the postholes at Lumbini are indicative of a tree shrine, ritual activity could have commenced either during or shortly after the life of the Buddha. The dates of the postholes would hence provide the first archaeological evidence for the date of the Buddha. At his mahaparanirvana, the Buddha identified Lumbini as a focus for pilgrimage (Beal 1869: 126), and thus it may be argued that formalised ritual activity began soon after this event.

\section{Conclusion}

The sequence at Lumbini is a microcosm for the development of Buddhism from a localised cult to a global religion as the shrine was transformed from a cardinally orientated timber structure with a localised ceramic package (Verardi 2007: 245) into a monumental Asokanperiod temple and pillar complex inscribing it as a site of imperial pilgrimage. This development continued through its nineteenth-century 'rediscovery', twentieth-century archaeological investigations, and international recognition as a World Heritage Site. Not only has the current UNESCO project led to the recording and conservation of new monuments within the World Heritage site, it has also mapped the needs of heritage conservation against those of the increasing pilgrim numbers. The project has also afforded the opportunity to address several research questions relating to the archaeological signature of early Buddhism and we have confirmed Piggott's hypothesis regarding pre-Mauryan wooden architecture. The posthole alignment within the temple highlights the non-durable structures present at early Buddhist ritual sites. These non-durable precursors provided the foundation for subsequent brick structures and it is clear that certain cosmological traits were already present, such as the cardinal definition of sacred and profane. The methodological bias in South Asian archaeology towards identifying and conserving brick walls has most likely contributed to a state of affairs where underlying traces of earlier wooden architecture

(C) Antiquity Publications Ltd. 

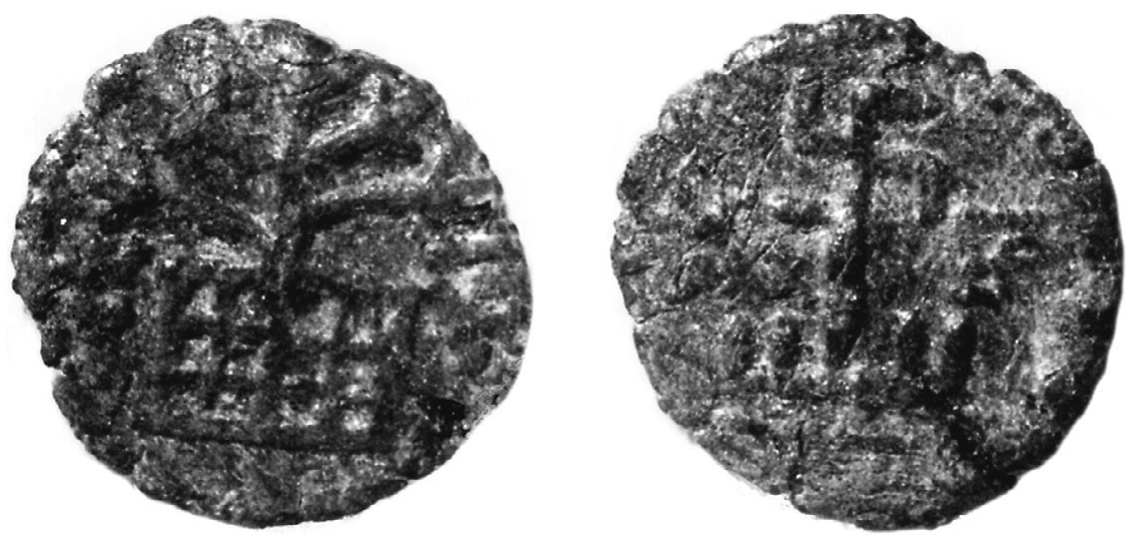

Figure 13. Tree and swastika coin from Anuradhapura, Sri Lanka. Sf\# 2846, Period G: 350 BC-AD 150 (from Coningham 2006).

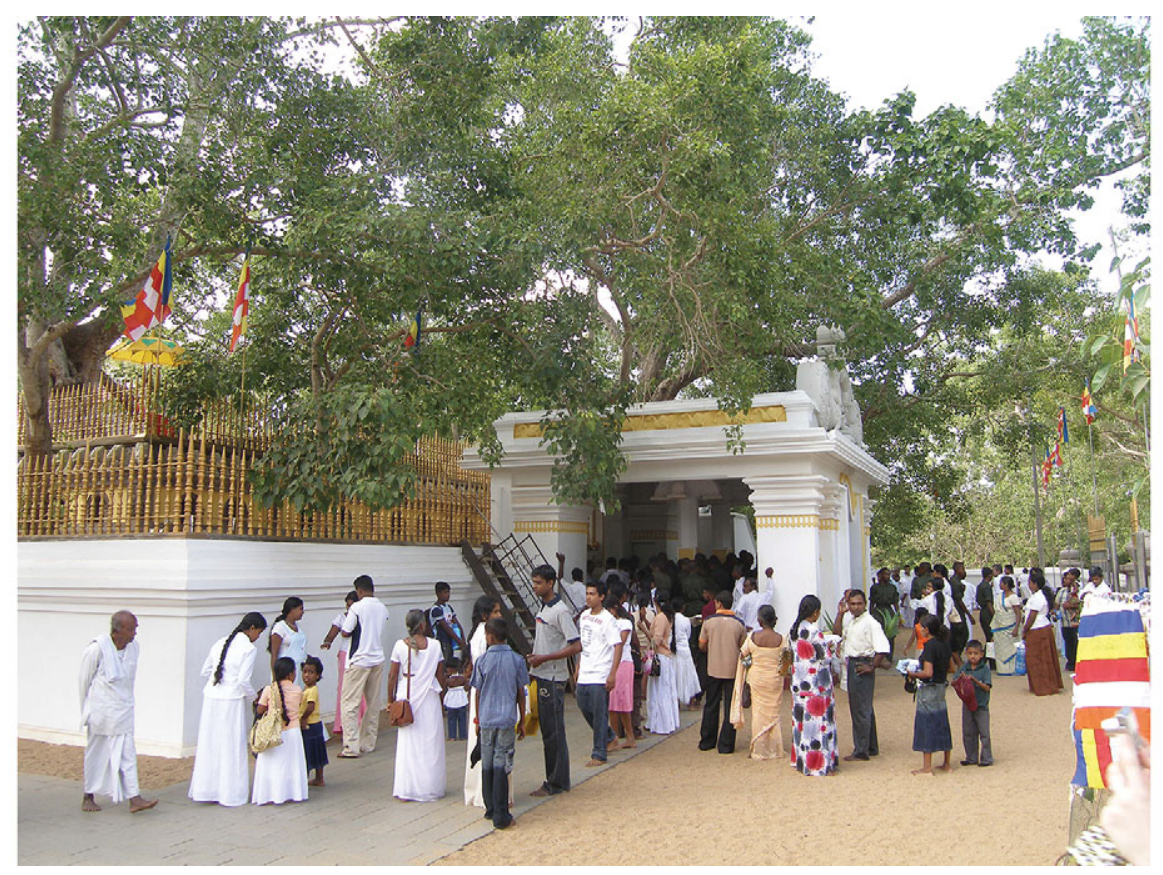

Figure 14. The Sri Mahabodhi in Anuradhapura. Originally planted from a cutting of the Bodhi tree at Bodh Gaya, the tree has been replanted, replenished and memorialised over time. Photo: authors.

have been overlooked. Indeed, despite hundreds of excavations, timber architecture has only been identified at the later site of Pauni, where two phases of postholes for timber railings were later replaced by stone railings (Deo \& Joshi 1972: 26-27). Such evidence highlights the problematic nature of the 'Mauryan Horizon' and the paucity of evidence supporting our current concepts of the character of the early Buddhist shrines.

Furthermore, rather than being driven by the model of Asokan patronage, evidence from Lumbini suggests a gradual development of ritual architecture. This dovetails with Monica (C) Antiquity Publications Ltd. 
Smith's re-examination of Mauryan political authority. Refuting assertions of a powerful, centralised empire, Smith has argued that Asokan pillars and edicts represented investment locations rather than territorial control and that they were sited along communication and trade networks (Smith 2005). As such, much of the Subcontinent was not under direct Mauryan rule but bound to networks of social integration, with the adoption of Buddhism as a major catalyst (Smith 2005: 843). This re-imagining has had a direct impact on our understandings of the development of Buddhism and patronage, particularly at Lumbini. The wooden postholes at Lumbini suggest an early phase of activity, predating imperial patronage. The description of this shrine as a garden suggests that it may have been the recipient of earlier phases of patronage from local elites and donors, just as we see in Sri Lanka (Coningham 1999: 22). As such, the narrative of Lumbini's establishment as a pilgrimage site under Asokan patronage must be modified since it is clear that the site had already undergone embellishment for centuries. In order to investigate such hypotheses, however, stratigraphically controlled excavations are required at Buddhist sites throughout South Asia. Such a research trajectory has the potential to provide yet more evidence for the earliest expressions of Buddhist architecture and ritual practice. Furthermore, if the posthole alignment is related to the earliest veneration of the Buddha, shortly after his mahaparanirvana, we may also have the first archaeological evidence regarding the date of the life of Buddha. As noted above, dates of the sixth century BC lend support to the longer chronology and not the shorter chronology in the vicinity of $480 \mathrm{BC}$ favoured by a number of prominent textual scholars like Heinz Bechert (1995: 34). It is important to note, however, that such assertions require further analysis and excavation, not only at Lumbini, but also at the three other sites identified by the Buddha as places for pilgrimage.

Broadening this debate, similar approaches could be focused on the study of narratives of other religious leaders. Although engagement with the archaeology of ritual and religion has increased (Insoll 2001, 2011), most studies remain dominated by frameworks supported by textual and historical narratives. For example, archaeology has been neglected in discussions of Jainism, a heterodoxical religious movement contemporary with Buddhism. Enquiry remains focused on sculpture, durable architecture, epigraphy and texts. Anthropological studies have begun to deconstruct disparities between the precepts and practice of Jain mendicants and lay communities (Cort 2010) but archaeology could further aid discussion. Indeed, the dominance of Buddhism within South Asia is projected through Mauryan patronage and, as such, may represent propaganda used to legitimate the tenuous hegemony evident at that time. It is highly likely that other movements, including Jainism, Brahmanism and localised cult activities were active, in both conflict and coexistence with early Buddhism. Archaeological data may help elucidate this complex interchange of action in order to contrast and supplement textual narratives. In conclusion, the recent excavations at Lumbini have demonstrated the possibilities for investigating early Buddhist architecture and highlighted the potential of archaeology as an avenue of enquiry for evidence relating to the nature and date of early Buddhism.

\section{Acknowledgements}

The authors express their gratitude to the Government of Nepal, the Lumbini Development Trust, the Department of Archaeology (Government of Nepal), UNESCO Kathmandu Office, the communities of 


\section{The earliest Buddhist shrine}

Lumbini, Durham University and the University of Stirling for enabling our research. We also express our gratitude to the following for their assistance: Sri Acharya Karma Sangbo Sherpa, Mod Raj Dotel, Bhesh Narayan Dahal, Ajitman Tamang, Rajendra Thapa, Axel Plathe, Dr Roland Lin, Natsuko Hashimoto, Basanta Bidari, Ram Bahadur Kunwar, Suresh Suras Shreshta, Krishna Bahadur KC, Himal Kumar Upreti, Kai Weise, Nabha Basnyat-Thapa, Nipuna Shresta, Professor Yukio Nishimura and Dr Costantino Meucci. We are grateful to two referees, Professor Nancy Wilkie and Dr Julia Shaw, for their feedback on an earlier version of this paper. We also thank Dr Armin Schmidt, Joanne Shoebridge, Armineh Marghussian, Natalie Swann, Richard Villis and Mark Houshold as well as the staff of the Lumbini Development Trust, the Department of Archaeology (Government of Nepal) and the staff and students of Tribhuvan University, Nepal, for their help in the field. We would also like to record our gratitude to Ira Block for permission to use his images of Lumbini, and Durham University for the use of images from the collection of Sir John Marshall. The fieldwork was generously supported by the Japanese Funds-in-Trust for UNESCO with additional funding from Durham University and the National Geographic Society.

\section{References}

ALLCHIN, F.R. 1995. Mauryan architecture and art, in F.R. Allchin (ed.) The archaeology of Early Historic South Asia: the emergence of cities and states: 222-73. Cambridge: Cambridge University Press.

BANDARANAYAKE, S.D. 1974. Sinhalese monastic architecture: the Viharas of Anuradhapura. Leiden: E.J. Brill.

BEAL, S. 1869. Travels of Fah-Hian and Sung-Yun. London: Trubner \& Co.

BECHERT, H. 1995. Introductory essay: the dates of the historical Buddha- a controversial issue, in $\mathrm{H}$. Bechert (ed.) When did the Buddha live? The controversy on the dating of the historical Buddha: 11-36. Delhi: Sri Satguru.

BIDARI, B. 2002. Lumbini: a haven of sacred refuge. Kathmandu: Bidari.

BopearachCHI, O. 2006. Coins, in R.A.E. Coningham (ed.) Anuradhapura: the British-Sri Lankan excavations at Anuradhapura Salgahawatta 2, Vol. 2: the artefacts (British Archaeological Reports international series 1508): 7-26. Oxford: Archaeopress.

Bopearachchi, O. \& W. Pieper. 1998. Ancient Indian coins. Turnhout: Brepols.

Bronk Ramsey, C. 1995. Radiocarbon calibration and analysis of stratigraphy: the OxCal program. Radiocarbon 37: 425-30.

- 2001. Development of the radiocarbon program OxCal. Radiocarbon 43: 355-63.

Coningham, R.A.E. 1998. Buddhism rematerialised and the archaeology of the Gautama Buddha. Cambridge Archaeological Journal 8: 121-26.

- 1999. Anuradhapura, volume I: the site. Oxford: Archaeopress.

- 2001. The archaeology of Buddhism, in T. Insoll (ed.) Archaeology and world religion: 61-95. London: Routledge.

- 2005. South Asia: from early villages to Buddhism, in C. Scarre (ed.) The human past: world prehistory and the development of human societies: 518-51.

London: Thames \& Hudson.

- 2006 (ed.). Anuradhapura: the British-Sri Lankan excavations at Anuradhapura Salgahawatta 2, Vol. 2: the artefacts (British Archaeological Reports international series 1508). Oxford: Archaeopress.

- 2011. The archaeology of Buddhism, in T. Insoll (ed.) The Oxford handbook of the archaeology of ritual and religion: 932-45. Oxford: Oxford University Press.

CONIngham, R.A.E \& K.P. ACHARYA. 2011.

Identifying, evaluating and interpreting the physical signature of Lumbini for presentation, management and long-term protection: report of season one of activity 2. Report prepared for UNESCO, Kathmandu.

- 2012. Identifying, evaluating and interpreting the physical signature of Lumbini for presentation, management and long-term protection: report of season two of activity 2 . Report prepared for UNESCO, Kathmandu.

Coningham, R.A.E. \& J.-F. Milou. 2001. Reactive monitoring mission to Lumbini, birthplace of Lord Buddha: report and recommendations of a UNESCO mission to Nepal. Kathmandu: UNESCO Kathmandu.

Coningham, R.A.E., A.R. SCHmidT \& K.M. STRICKLAND. 2011. A cultural and environmental monitoring of the UNESCO World Heritage Site of Lumbini, Nepal. Ancient Nepal 176: 1-8.

COOMARASWAMY, A.K. 1930. Early Indian architecture: II. Bodhigaras. Eastern Art 2: 225-35.

CORT, J.E. 2010. World renouncing monks and world celebrating temples and icons in Jainism, in H.P. Ray (ed.) Archaeology and text: the temple in South Asia: 268-95. Delhi: Oxford University Press.

Cunningham, A. 1879. The stûpa of Bharhut. London: W.H. Allen \& Co.

(C) Antiquity Publications Ltd. 
- 1891. Coins of ancient India from the earliest times to the seventh century. London: Quartich.

DEHEJIA, V. 1997. Discourses in early Buddhist art: visual narratives of India. Delhi: Munshiram Manoharlal.

DeO, S.B. \& J.P. JosHI. 1972. Pauni excavation (1969-1970). Nagpur: Nagpur University.

DitTmann, R. 1984. Problems in the identification of an Achaemenid and Mauryan Horizon. Archaeologische Mitteilungen aus Iran 17: 73-102.

FALK, H. 2006. Asokan sites and artefacts: a source book with bibliography. Mainz: Philipp von Zabern.

Geiger, W. 1929. The Mahavamsa. Colombo: Ceylon Government Information Department.

Hartel, H. 1995. Archaeological research on ancient Buddhist sites, in H. Bechert (ed.) When did the Buddha live? The controversy on the dating of the historical Buddha: 141-60. Delhi: Sri Satguru.

HarveY, 1984. The symbolism of the early stupa. The Journal of International Association of Buddhist Studies 7(2): 67-93.

INSOLL, T. (ed.). 2001. Archaeology and world religion. London: Routledge.

- (ed.). 2011. The Oxford handbook of ritual and religion. Oxford: Oxford University Press.

IRWIN, J.C. 1973. 'Asokan' pillars: a reassessment of the evidence. The Burlington Magazine 115: 706-20.

- 1976. 'Asokan' pillars: a reassessment of the evidence, IV: symbolism. The Burlington Magazine 118: 734-53.

- 1979. The stupa and the cosmic axis: the archaeological evidence, in M. Taddei (ed.) South Asian archaeology 1977: 799-846. Naples: Istituto Universitario Orientale.

- 1982. The sacred anthill and the cult of the primordial mound. History of Religions 21: 339-60.

- 1983. The ancient pillar-cult at Prayaga (Allahabad): its pre-Asokan origins. Journal of the Royal Asiatic Society of Great Britain and Northern Ireland 2: 253-80.

KNOX, R. 1681. An historical relation of the island Ceylon, in the East Indies. London: Richard Chiswell.

Marcus Fernando, W.N. 1965. Ancient city of Anuradhapura. Colombo: Department of Archaeology.

Mitra, D. 1971. Buddhist monuments. Calcutta: Samsad.

- 1972. Excavations at Tilaura-kot and Kodan and the explorations in the Nepalese Tarai. Calcutta: His Majesty's Government of Nepal.
MUKHERJI, P.C. 1901. A report on a tour of exploration of the antiquities of Kapilavastu Tarai of Nepal during February and March 1899. Calcutta: Office of the Superintendent of Government Printing, India.

Nugteren, A. 2005. Belief, bounty, and beauty: rituals around sacred trees in India. Leiden: Brill.

Paranavitana, S. 1946. The stupa in Ceylon (Memoirs of the Archaeological Survey of Ceylon 5). Colombo: Ceylon Government Press.

PIEPER, J. 1991. Arboreal art and architecture in India, in K. Vatsyayan (ed.) Concepts of space: ancient and modern: 333-41. New Delhi: Indira Gandhi National Centre for the Arts.

PIgGOTT, S. 1943. The earliest Buddhist shrines. Antiquity 17: 1-10.

- 1944. Nomad house-sites in the western Himalayas. Man 44: 150-52.

- 1945. Some ancient cities of India. London: Oxford University Press.

- 1947. A new prehistoric ceramic from Baluchistan. Ancient India 3: 131-42.

- 1950. Prehistoric India to 1000 BC. Harmondsworth: Penguin.

RIJAL, K. 1979. Archaeological remains of Kapilvastu, Lumbini and Devadaha. Kathmandu: Educational Enterprises.

SAHNI, R. 1937. Archaeological remains and excavations at Bairat. Jaipur: Jaipur State Department of Archaeology and Historical Research.

SCHOPEN, G. 1997. Bones, stones, and Buddhist monks: collected papers on the archaeology, epigraphy, and texts of monastic Buddhism in India. Honolulu: University of Hawaii Press.

SINGH, P. 1994. Excavations at Narhan (1984-1989). Delhi: BR.

SMITH, M. 2005. Networks, territories and the cartography of ancient states. Annals of the Association of American Geographers 95: 832-49.

Trautmann, T.R. \& C.M. SinOpOli. 2002. In the beginning was the word: excavating the relations between history and archaeology in South Asia. Journal of the Economic and Social History of the Orient 45: 492-523.

UesaKA, S. 2001. Archaeological research at Maya Devi Temple, Lumbini. Tokyo: Japan Buddhist Federation.

Verard, G. 2007. Excavations at Gotihawa and Pipri, Kapilbastu District, Nepal. Rome: Istituto Italiano per l'Africa e l'Oriente.

Received: 21 December 2012; Accepted: 30 April 2013; Revised: 7 May 2013

(C) Antiquity Publications Ltd. 